\title{
Autologous tenocyte stem cell injection for chronic tendinosis secondary to ruptured Achilles tendon repair: a case study
}

Peter Manuel

From Australasian Podiatry Conference 2015

Queensland, Australia. 6-8 May 2015

\section{Background}

Achilles tendinopathy is a common pathology with limited treatment options. This case study displays a novel approach using autologous tendon stem cells (tenocytes) injected into a chronically affected Achilles tendon following a failed repair of an Achilles tendon rupture.

\section{Process}

Tenocytes were harvested from the patient's patella tendon and prepared using Orthocell regeneration technology. The tenocytes were multiplied and placed into an injectable scaffold, then injected under ultrasound guidance into the diseased tendon.

\section{Findings}

The patient ruptured the Achilles tendon working as a nurse and underwent an orthopaedic surgery primary repair. At 6 months post operatively the patient had developed chronic tendinopathy affecting over $80 \%$ of the Achilles tendon. The patient was referred for opinion and had been off work for over 6 months with limitation in activities of daily living.

The patient underwent a surgical excision of a posterior calcaneal exostosis and debridement of the diseased Achilles tendon and harvest of tenocytes. 13 weeks postsurgery the tenocytes were injected into the Achilles tendon. The patient returned to full time work and normal activities of daily living at 8 weeks post injection. MRI studies were performed pre and post injection to assess diseased state of the tendon.

\section{Conclusions}

Autologous tenocyte injection provides the clinician with a tool for treatment of chronic tendinopathy, where other treatment options have failed.

\section{Conflict of interest}

Mr Peter Manuel has no financial relationship with Orthocell nor received any funding for this case study.

Published: 22 September 2015

\section{doi:10.1186/1757-1146-8-S2-027}

Cite this article as: Manuel: Autologous tenocyte stem cell injection for chronic tendinosis secondary to ruptured Achilles tendon repair: a case study. Journal of Foot and Ankle Research 2015 8(Suppl 2):O27.

Submit your next manuscript to BioMed Central and take full advantage of:

- Convenient online submission

- Thorough peer review

- No space constraints or color figure charges

- Immediate publication on acceptance

- Inclusion in PubMed, CAS, Scopus and Google Scholar

- Research which is freely available for redistribution 